Article

\title{
Diverse Bacterial PKS Sequences Derived From Okadaic Acid-Producing Dinoflagellates
}

\author{
Roberto Perez ${ }^{1, \dagger}$, Li Liu ${ }^{1}$, Jose Lopez ${ }^{2}$, Tianying An ${ }^{1}$ and Kathleen S. Rein ${ }^{1, *}$ \\ 1 Department of Chemistry and Biochemistry, Florida International University, Miami, FL 33199, USA \\ 2 Oceanographic Center, Nova Southeastern University, Dania Beach FL 33004, USA
}

E-mails: rperez@med.miami.edu (R. P.) 1liu004@fiu.edu (L. L.); tianying@fiu.edu (T. A.); joslo@nova.edu (J. L.); reink@fiu.edu (K. R.)

${ }^{\dagger}$ Current Address: Department of Dermatology and Cutaneous Surgery, University of Miami, Miller School of Medicine, Miami, Florida 33136.

* Author to whom correspondence should be addressed; E-mail: reink@fiu.edu; Tel.: +1-305-3486682; FAX: +1-305-348-3772.

Received: 29 February 2008; in revised form: 9 May 2008 / Accepted: 13 May 2008 / Published: 22 May 2008

\begin{abstract}
Okadaic acid (OA) and the related dinophysistoxins are isolated from dinoflagellates of the genus Prorocentrum and Dinophysis. Bacteria of the Roseobacter group have been associated with okadaic acid producing dinoflagellates and have been previously implicated in OA production. Analysis of $16 \mathrm{~S}$ rRNA libraries reveals that Roseobacter are the most abundant bacteria associated with OA producing dinoflagellates of the genus Prorocentrum and are not found in association with non-toxic dinoflagellates. While some polyketide synthase (PKS) genes form a highly supported Prorocentrum clade, most appear to be bacterial, but unrelated to Roseobacter or Alpha-Proteobacterial PKSs or those derived from other Alveolates Karenia brevis or Crytosporidium parvum.
\end{abstract}

Keywords: okadaic acid, polyketide, polyketide synthase, biosynthesis, Roseobacter. 


\section{Introduction}

Dinoflagellates of the genus Prorocentrum, most closely related to the genus Dinophysis, were first characterized by Ehrenberg in 1833. Species of Prorocentrum can be planktonic, benthic, or epiphytic and are distributed globally, most diversely in tropical or sub-tropical marine environments. They are mostly photosynthetic but are known to consume other organisms. The genus is possibly best known for the production of the diarrheic shellfish poisoning (DSP) class of toxins which include okadaic (OA) acid and the dinophysistoxins (DTX) (Figure 1) [1].

DSP has been associated with the consumption of mussels, scallops, or clams tainted with OA and its analogs or derivatives. The acute symptoms of DSP include diarrhea, nausea, vomiting and abdominal pain. Outbreaks have been documented in Japan, Spain, France, Chile, Thailand, New Zealand, Canada, Uruguay, Italy, Ireland, Portugal and Norway [2]. DSP is part of the harmful algae phenomenon which is a risk to health and economies on a global scale [3]. The parent of this group of toxins, OA was first isolated from the sponges, Halichondria okadai and H. melanodocia [4]. However it was later isolated from laboratory cultures of several dinoflagellates belonging to the genera Prorocentrum and Dinophysis, including P. lima, P. hoffmannianum, P. concavum, P. maculosum, P. belizeanum, P. faustiae, P. arenarium, D. acuta and D. fortii [5-13]. In addition to OA, several related polyethers are isolated from these dinoflagellates, including the dinophysis toxins, DTX-1, DTX-2, DTX-3, DTX-4, DTX-5, DTX-5a, DTX-5b acanthifolicin, and multiple diol and sulfated esters of OA and DTXs [14-22]. OA, DTX-1, DTX-2 and acanthifolicin (the 9, 10 episulfide of OA) are inhibitors of protein phosphatases PP-1 and PP-2A [23]. As a result, OA has enjoyed considerable utility as a tool to identify and study processes which are regulated by protein phosphorylation/ dephosporylation.

Figure 1. Structures of okadaic acid (OA) and the dinophysistoxins (DTXs).
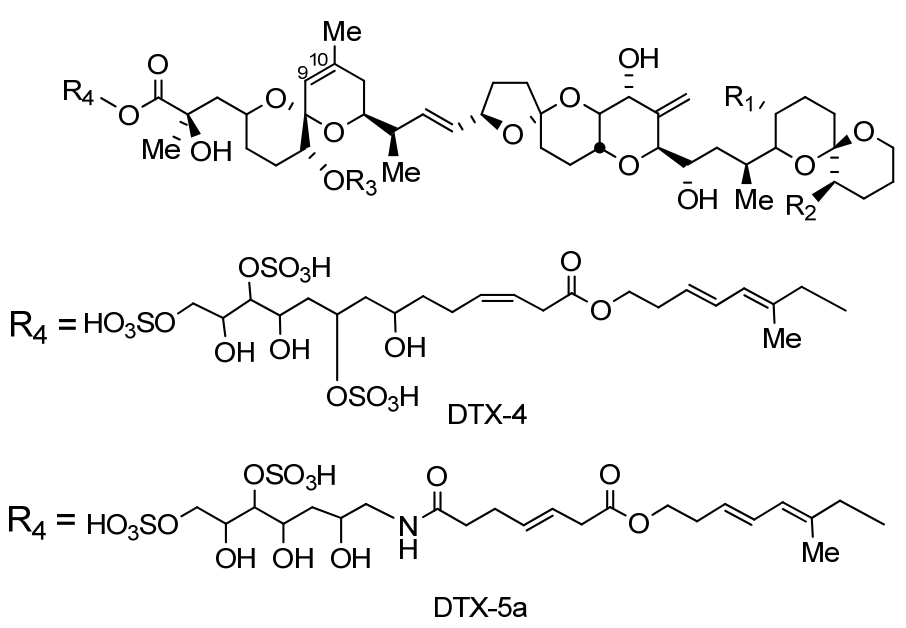

$\underline{\mathrm{R}}_{1} \quad \underline{\mathrm{R}}_{2} \quad \underline{\mathrm{R}}_{3} \quad \underline{\mathrm{R}}_{4}$

$\begin{array}{lllll}\text { Okadaic acid } & \mathrm{CH}_{3} & \mathrm{H} & \mathrm{H} & \mathrm{H} \\ \text { DTX-1 } & \mathrm{CH}_{3} & \mathrm{CH}_{3} & \mathrm{H} & \mathrm{H} \\ \text { DTX-2 } & \mathrm{H} & \mathrm{CH}_{3} & \mathrm{H} & \mathrm{H} \\ \text { DTX-3 } & \mathrm{CH}_{3} & \mathrm{CH}_{3} & \text { acyl } & \mathrm{H} \\ \text { DTX-4 } & \mathrm{CH}_{3} & \mathrm{H} & \mathrm{H} & \text { see left } \\ \text { DTX-5a } & \mathrm{CH}_{3} & \mathrm{H} & \mathrm{H} & \text { see left }\end{array}$

Stable isotope incorporation experiments have demonstrated that OA and the DTXs are essentially polyketides, although some anomalies in their construction have been identified. [24-26] Polyketides are structurally diverse natural products which share a common biogenic origin. In a fashion analogous to fatty acid biosynthesis, the carbon chain is constructed via the sequential Claisen condensation of small carboxylic acid units catalyzed by a polyketide synthase (PKS). Traditionally, PKS enzymes 
have been classified as Type I, Type II, or Type III based on the organization of modules and whether they are used iteratively or not [27]. Type I enzymes are analogous to the Type I fatty acid synthases (FAS). The enzymes consist of large multifunctional, modular proteins. Each module contains the functional domains required for a single round of chain extension. This is in contrast to the Type I FAS which is a multi-funtional protein composed of a single module which is used in an iterative fashion. Type II PKSs are multi-enzyme complexes that carry out their functions iteratively. Type III PKS also are iterative enzymes which are responsible for the production of flavonoids, stilbenes, quinoline alkaloids, and acridine alkaloids [28]. Numerous polyketide biosynthetic pathways have been identified from bacteria, plants and fungi. In part due to the large size and complexity of the dinoflagellate genome, no biosynthetic pathway has been identified from this class of organism. However, the structures of the DSP toxins would suggest that they are made by a Type I modular PKS. Indeed, Type I PKS genes have been amplified from cultures of polyketide toxin producing dinoflagellates including P. lima [29]. Furthermore, Type I PKS genes have been identified from the related organism Cryptosporidium parvum [30].

There is a long standing controversy of whether dinoflagellates actually produce the toxins associated with them or if the compounds have a bacterial origin. Many toxin producing dinoflagellates have not been maintained in the absence of bacteria for an extended period of time. $P$. lima and associated bacteria seem to co-exist on several levels. Bacteria are known to be attached to the surface of the dinoflagellate, residing in the sticky mucus-like phycosphere. However, there is little evidence that $P$. lima contains endosymbiotic or internal bacteria. An ultrastrucural study of the alga has revealed that only "a few percent" of cells contain bacteria-like inclusion bodies residing near the theca of $P$. lima. Additionally, the inclusions are surrounded by a double membrane and contain fibrous material similar to bacterial nucleoids. Interestingly, the inclusions are compartmentalized within the $P$. lima cells by a third membrane [31]. Based on precedence, it seems plausible that these inclusions are indeed bacteria. P. micans, for example, has been shown to have bacteria present beneath the theca and attached to the surface [32]. Additionally, intracellular bacteria have been observed in several toxic dinoflagellates, including, Alexandrium spp. [33] and Heterocapsa spp. [34]. Most interesting, perhaps, is the identification of endosymbiotic bacteria in cells of the DSP toxin producing dinoflagellate, Dinophysis acuminata [35].

Extra-cellular bacteria, free-living or attached to $P$. lima, have shown interesting characteristics. As is common in marine environments, they are usually Gram negative Alpha-Proteobacteria. However, the $P$. lima associated bacteria are quite large $(2 \mu \mathrm{m})$, an unusual occurrence in marine systems. This is indicative of a nutrient rich environment and high metabolic activity [31]. Bacteria from P. lima seem to be mostly of the Roseobacter genus, although this may be due to selection by culturing or molecular techniques. Regardless, there is at least one reported instance of three bacterial strains producing OA. The bacteria were identified as Roseobacter algicola, Roseobacter denitrificans, and Roseobacter litoralis [36]. Unfortunately, there is no mention of extraction or testing methods which would allow for repetition of the experiments. The bacteria were later shown to be non-toxic by brine shrimp assay. Extracts of the $P$. lima cultures from which the bacteria were isolated were determined to be toxic to brine shrimp indicating that the bacteria may not be producing toxin or may lose toxicity upon culture [37]. 
The aim of this work was to assess both OA producing and non-producing species of the genus Prorocentrum for the presence of PKS encoding genes. Presumably OA producing dinoflagellates would have the same or similar polyketide synthases. Concurrently, we surveyed the bacteria associated with OA producing and non-producing species of Prorocentrum for the presence of common bacteria by sequencing of $16 \mathrm{~S}$ rRNA libraries.

\section{Results and Discussion}

Cultures of dinoflagellates $P$. lima, two strains of $P$. hoffmanianum (CCMP683 and CCMP2804), P. rhathymum (CCMP2933), P. micans (CCMP2772) and $P$. donghaiense [38], were screened for the production of OA or DTXs by protein phosphatase inhibition assay and by DSP ELISA (Table 1). As anticipated, $P$. lima and both strains of $P$. hoffmannianum were positive in both assays whereas $P$. micans and $P$. donghaiense were negative in both assays. Unanticipated were the small, but detectable amounts of OA equivalents in P. rhathymum by both PP2A inhibition and ELISA. $P$. rhathymum was first described in 1979 by Loeblich [39]. After it's initial description, the $P$. rhathymum taxonomy was dissolved and reclassified as $P$. mexicanum [40, 41]. After much debate the species has recently been reinstated as a unique organism [42]. Our sequence analysis of the large subunit ribosomal genes agrees with the concept that $P$. mexicanum and $P$. rhathymum are separate species [43]. Nonetheless, neither $P$. rhathymum nor $P$. mexicanum have been reported to produce DSP toxins.

Table 1. Extracellular Concentrations of OA equivalents.

\begin{tabular}{lll}
\hline & $\begin{array}{l}\text { OA equivalents by } \\
\text { PP2A (ppb } \pm \text { sd) }\end{array}$ & $\begin{array}{l}\text { OA equivalents by } \\
\text { ELISA(range in ppb) }\end{array}$ \\
\hline P. lima & $235 \pm 5$ & $328 \pm 6$ \\
P. hoffmanianum & $97 \pm 3$ & $81 \pm 1$ \\
P. rhathymum & $0.45 \pm 0.004$ & $0.57 \pm 0.003$ \\
P. micans & $\mathrm{nd}^{\mathrm{a}}$ & $\mathrm{nd}^{\mathrm{a}}$ \\
P. donghaiense & $\mathrm{nd}^{\mathrm{a}}$ & $\mathrm{nd}^{\mathrm{a}}$ \\
\hline \multicolumn{1}{c}{${ }^{\mathrm{a}}$ Not detectable } & $\mathrm{n}=3$ for PP2A & $\mathrm{n}=2$ for ELISA
\end{tabular}

Primers (16SF and 16SR, Table 2) to the bacterial small subunit rRNA gene [37] were used to amplify PCR products from the six strains of Prorocentrum under investigation as well as extracellular bacteria separated from $P$. lima cultures by tangential flow filtration (TFF bacteria). Gel-purified PCR amplicons were used to construct $16 \mathrm{~S}$ libraries resulting in a total of 357 cloned PCR products (48 from each species and TFF bacteria and 69 from P. hoffmanianum (CCMP2804)). These sequences were aligned and submitted to BLASTN for best match identification. Comparison of $16 \mathrm{~S}$ libraries reveal that over $35 \%$ of all sequences matched most closely with bacteria of the genus Roseobacter (Table 3). Furthermore, bacteria of the genus Roseobacter represented over $50 \%$ of all sequences originating from OA producing strains of dinoflagellates and were not identified in the non-toxic species $P$. donghaiense or $P$. micans. The identification of Roseobacter in association with $P$. lima is not surprising since several species of Roseobacter were originally isolated from P. lima 
cultures [36]. Additionally, some strains of Roseobacter algicola have been implicated in DSP toxin production [43]. Interestingly, $R$. prionitis was found to be a major constituent of the bacterial library from $P$. lima but was not found in the TFF bacterial fraction suggesting that it is intimately associated with $P$. lima. In fact, the only bacteria identified which were both associated with the $P$. lima cells and in the bulk media was $R$. pelophilus indicating that the bacterial consortium associated with the phycosphere is significantly different from that in the bulk media.

Table 2. Sequences of PCR primers.

\begin{tabular}{l|l|l}
\hline Name & Sequence $\left(\mathbf{5}^{\prime} \rightarrow \mathbf{3}^{\prime}\right)$ & Product Size \\
\hline PKS4U & MGIGARGCIYTICARATGGAYCCICARCARMG & $700 \mathrm{bp}$ \\
PKS5L & GGRTCNCCIARYTGIGTICCIGTICCRTGIGC & \\
$16 \mathrm{SF}$ & GGAGAGTTTGATCATGGCT & $1.3 \mathrm{kbp}$ \\
$16 \mathrm{SR}$ & ACGGYTACCTTGTTACGACTT & \\
\hline
\end{tabular}

Recently, genes associated with secondary metabolite biosynthesis, PKSs and non-ribosomal peptide synthetases (NRPS), have been amplified from bacteria of the Roseobacter clade and it has been suggested that Roseobacter should be considered a potential source of new natural products [44]. The phylogeny of PKS genes amplified from Roseobacter were found to be related to the phylogeny based on the analysis of 16S rRNA. This report and the abundance of Roseobacter found associated with our toxic dinoflagellate cultures, prompted us to examine the PKS encoding genes from cultures of OA producing dinoflagellates to determine if they are related to each other or to other PKS genes originating from Roseobacter. Degenerate primers (PKS4U and PKS5L, Table 2) to the $\beta$-ketoacyl synthase domain of PKS genes were used to amplify PCR products from the six strains of Prorocentrum under investigation as well as bacteria separated from $P$. lima cultures by tangential flow filtration (TFF bacteria). Gel-purified PCR amplicons were used to construct PKS libraries resulting in a total of 280 cloned PCR products (48 from each species except $P$. hoffmanianum (CCMP683) and TFF bacteria which produced 24 each and P. hoffmanianum (CCMP2804) which yielded 40). Analysis of the 280 resulting translated sequences by alignment (using DNA Star) and translated BLASTX identified a minimum of 16 unique type I PKS sequences (Table 4). One representative of each unique sequence was re-sequenced in both directions to obtain full length sequences of the PCR products (700 bp). Many highly similar sequences ( $>96 \%$ identity at the amino acid level) were identified from multiple species. These are indicated in Table 4.

Phylogenetic analysis was performed in order to infer potential organismal sources or relationships for each Prorocentrum-derived PKS amino acid sequence, but not absolute phylogenies per se, due to high sequence divergences and lack of optimal outgroups. Reference PKS entries retrieved from GenBank were thus included with new Prorocentrum PKS sequences and appear in the minimum evolution phylogeny shown in Figure 3. Similar to previous analyses [45], PKS pairwise distances that were used to construct the phylogeny, ranged widely $(2.2-75.8 \%)$. The distance tree shows that several Prorocentrum-derived PKS sequences appear dispersed with other bacterial PKS sequences in several branches of the tree, although one highly supported Prorocentrum symbiont clade includes several PKS sequences from $P$. hoffmannianum, and $P$. micans). No current Prorocentrum PKS 
sequences group with previously characterized Cryptosporidium parvum or Karenina brevis PKS sequences, supporting a potential prokaryotic source for OA. For example, some Prorocentrumderived sequences grouped with a divergent and heterogeneous group of bacterial PKS sequences, such as Halomonas, Nitrosomonas, and uncultured bacteria, which were added for reference within the tree. Again, it was interesting that none of the new Prorocentrum sequences appear related to Roseobacter or Alpha-Proteobacterial sequences. Also interesting is the grouping of OA-associated, and abundant P. hoffmannianum (19) and P. lima (4L) sequences with Actinomycetes Type I PKS sequences.

Table 3. Results of $16 \mathrm{~S}$ rRNA libraries indicating the best matches from nucleotide BLAST searches and frequency of occurrence within each library.

\begin{tabular}{|c|c|c|c|c|c|c|c|c|}
\hline $\begin{array}{l}\text { Accession } \\
\text { number }\end{array}$ & Nearest BLASTn Match Description & PL & TB & PH1 & PH2 & PR & PD & PM \\
\hline DQ167249 & Roseobacter prionitis & 28.5 & & 17 & & 60 & & \\
\hline AJ968652 & Roseobacter pelophilus & 28.5 & 37 & & & & & \\
\hline DQ120726 & Roseobacter sp. 812 & & 6 & 17 & & & & \\
\hline DQ104407 & Roseobacter sp. JL-351 & & & & 49 & & & \\
\hline DQ659415.1 & Roseobacter sp. COL2P & & & & 8.7 & & & \\
\hline AJ878874 & Thalassobius mediterraneus & & 6 & 9 & & & & \\
\hline AM420114.1 & Uncultured Alpha-Proteobacterium & & 6 & 9 & & & & \\
\hline AY162118 & Planctomycete GMD16E07 & & 6 & & & 22. & & \\
\hline AJ889010 & Stappia alba strain 5OM30 & & 6 & & & 5 & & \\
\hline AY163576 & Croceibacter atlanticus & & & & & 3 & 51 & \\
\hline EF414083 & Uncultured Bacteroidetes bacterium & & & & & 3 & & 3 \\
\hline Y15341 & Rhizobium sp. & 17.5 & & & & 3 & & \\
\hline AY654759 & Mucus bacterium 110 from $O$. patagonica & 4.5 & & & & & & \\
\hline AY258089 & Mesorhizobium sp. DG943 & 3 & & & & & & \\
\hline AF441991.1 & Uncultured CFB group bacterium clone & 3 & & & & & & \\
\hline EF12346.1 & Uncultured Gamma-Proteobacterium clone & 3 & & & & & & \\
\hline DQ446117 & Uncultured spirochete clone & 3 & & & & & & \\
\hline $\mathrm{AJ} 227758$ & Caulobacter henricii strain ATCC 15253 & & 9 & & & & & \\
\hline AY136121 & Marinobacter sp. MED106 & & 6 & & & & & \\
\hline AY701447 & Uncultured Bacteroidetes bacterium & & 6 & & & & & \\
\hline AM176885.1 & Uncultured bacterium clone SZB60 & & 6 & & & & & \\
\hline AY917783 & Uncultured bacterium clone 1971b-30 & & 6 & & & & & \\
\hline DQ811828 & Uncultured Delta-Proteobacterium clone & & & & 5.8 & & & \\
\hline AY162122 & MSB & & & & 4.3 & & & \\
\hline AY960750 & Planctomycete GMD14H10 & & & & 3 & & & \\
\hline AY345437 & Maribacter dokdonensis strain DSW-9 & & & & 3 & & & \\
\hline AY517632 & Bacterium K2-12 & & & & 3 & & & \\
\hline DQ513013 & Marinobacter flavimaris strain SW-145 & & & & 3 & & & \\
\hline DQ486493 & Uncultured bacterium clone FS140-15B-02 & & & & 3 & & & \\
\hline EU196324 & Gamma-Proteobacterium DG1253 & & & & 3 & & & \\
\hline EU148878 & Sphingomonas sp. NP31 & & & 12 & & & & \\
\hline EF106349 & Uncultured bacterium clone PP6-13 & & & 9 & & & & \\
\hline EF658677 & Uncultured planctomycete & & & 9 & & & & \\
\hline AY038570 & Uncultured bacterium clone YHSS3 & & & 9 & & & & \\
\hline AY 682384 & Uncultured alpha-Proteobacterium & & & 12 & & & & \\
\hline
\end{tabular}




\begin{tabular}{lllll}
\hline CP000264 & Kordiimonas & gwangyangensis & strain & 6 \\
EF658677.1 & GW14-5 & & 6
\end{tabular}

AY539822 Jannaschia sp. CCS1

AY258095 Uncultured bacterium clone YHSS3

$8.5 \quad 34$

EU249979 Gamma-Proteobacterium BT-P-1

4.5

AY664364 Sulfitobacter sp. DG1020

4.5

AY562560 Uncultured Pseudomonas sp

AM697073 Pseudoalteromonas sp. PM02

3

AY344411.1 Alpha proteobacterium CRA 4C

EF123623.1

Uncultured bacterium

EU107173.1

Unidentified bacterium clone K2-S-32

EF512127.1

Uncultured Bacteroidetes bacterium

AB255368.1

Pseudomonas sp. N9-1

DQ822527.1

Stappia alba strain

EU196324.1 Gilvibacter sediminis

Bacterium QM28 3

$\begin{array}{ll}\text { EU005335.1 } & \text { Bacterium QM28 } \\ \text { AB073564 } & \text { Sphingomonas sp. NP31 }\end{array}$

Uncultured alpha proteobacterium clone

G7-25

Cytophaga sp. MBIC04693

P. lima (PL), P. hoffmanianum (PH1, CCMP683 or PH2, CCMP2804), P. rhathymum (PR), P. micans (PM), P.donghaiense (PD), and TFF bacteria from P. lima (TB).

Table 4. Alignment results of the PKS libraries

\begin{tabular}{|l|l|ll|}
\hline $\begin{array}{l}\text { PKS } \\
\text { sequence } \\
\text { name }\end{array}$ & $\begin{array}{l}\text { Total } \\
\text { Occurrence } \\
\text { Frequency (\%) }\end{array}$ & Organism Libraries & \\
\hline PL 28L & 24 & PL, PD, PR, PM, \\
PH 19 & 18 & CCMP2804 & \\
PL 5L & 18 & CCMP683, TB & \\
PL 4L & 11 & PL, CCMP683, TB & \\
PL 9W & 1 & PL, CCMP683, TB \\
PH 26 & 0.5 & PL, TBCCMP683 & \\
PH 39 & 0.5 & CCMP683 \\
PR 25 & 1 & PR, CCMP2804 \\
PM 44 & 6 & PM \\
PM 4 & 3 & PM \\
PM 48 & 2 & PM \\
PM 20 & 0.5 & PM, CCMP2804 \\
PH1316 & 10 & CCMP2804 \\
PH1329 & 2 & CCMP2804 \\
PH1356 & 1 & CCMP2804 \\
PH1314 & 1 & CCMP2804 \\
\hline
\end{tabular}

P. lima (PL), P. hoffmanianum (CCMP683 or CCMP2804),

P. rhathymum (PR), P. micans (PM), P. donghaiense (PD), and TFF bacteria from P. lima (TB) 
Figure 3. Minimum evolution distance phylogeny generated with the neighbor-joining algorithm and mean pairwise distances of Prorocentrum-derived and reference PKS amino acid sequences. GenBank accession numbers are listed next to reference sequences. FAS sequences serve as outgroup. New sequences from this paper are type in boldface. Overall 450 amino acid residues were compared, and of those 81 sites were constant and 269 parsimony informative. After 500 iterations, bootstrap percentages $(>70 \%)$ are shown below each node, while other groups collapsed. Clades are labeled based on the most numerous member sequence. One highly supported Prorocentrum dominated clade is marked by an asterisk. Geometric shapes indicate the presence of okadaic acid in the source specimen (squares for relatively high OA levels in P. lima, and triangles for relatively low OA levels shown in Table 1). The minimum evolution distance score for this phylogeny was 10.11 . The bar on the left shows a scale of 0.10 amino acid residue distance along each branch.

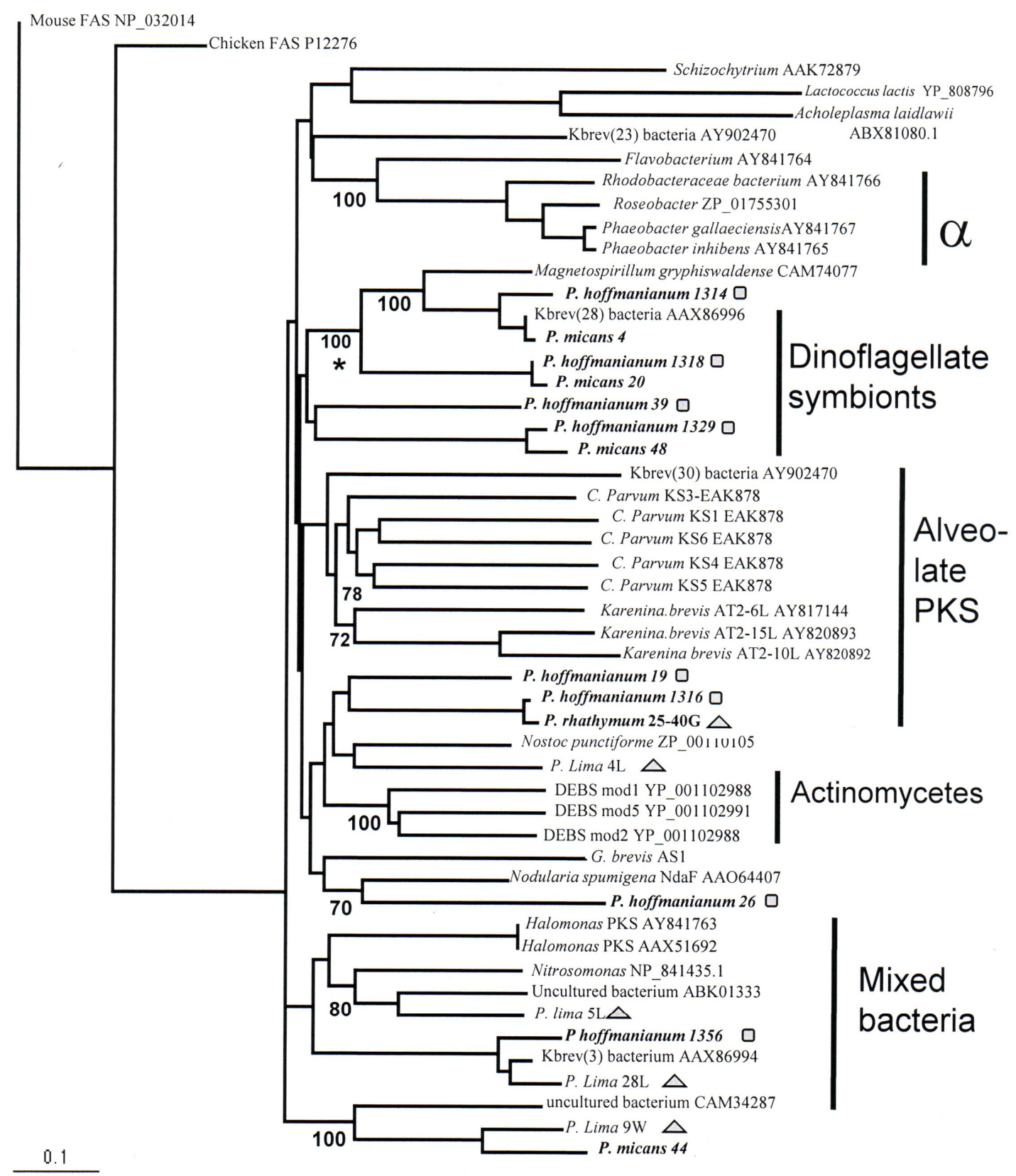


Outgroup selection did appear to have an influence on tree topology. When vertebrate FAS sequences were excluded from reconstructions, $P$. lima $28 \mathrm{~L}$, one of the most frequent PKS-derived sequences in these libraries (Table 4) and P. hoffmannianum 1356, often took a basal position near fatty acid synthases (FAS) in the phylogeny. This can be explained by the high amino acid sequence similarities (92 and $99 \%$, respectively) both share to some fatty acid synthases in BLASTP searches.

Other phylogenetic methods such as maximum parsimony and maximum likelihood, as well as different outgroup sequences (e.g. archaeal PKSs) were also applied to this dataset, but yielded similar groupings and the dispersal of "Prorocentrum-derived" PKSs in different parts of the trees.

\section{Conclusion}

At this stage, although there is evidence for a strong association of Alpha-Proteobacterial microbes with multiple Prorocentrum species in this study, we cannot easily equate or reconcile the 16S rRNA with the current PKS sequence data. We were expecting to find distinct Roseobacteria-like PKS sequences in the recombinant library, which may also be correlated with OA incidence. Of course, this lack could also be attributed to the probable incompleteness of both datasets, as all possible sequences have not been amplified, cloned or sequenced. Alternatively, the predominant PKS library sequences (e.g. PL 28L, PH 19, PL5L, etc) could be associated with some of the various "uncultured" or anonymous bacteria yet to characterized in Table 3. Nonetheless, the PKS phylogenetic analysis indicates that a Prorocentrum-specific bacterial PKS clade appears to exist, along with more dispersed Prorocentrum-derived sequences. These data leave open the possibility that OA production could stem from one of these bacterial sources. Further experimentation, such as culturing one of these strains for OA production would then constitute a logical next step.

\section{Experimental Section}

\subsection{Culture Conditions}

Cultures were maintained in variety of media: RE (P. hoffmannianum CCMP2804, P. donghaiense, K (P. rhathymum CCMP2933), L1-Si (P. micans CCMP2772), f/2-Si (P. lima and P. hoffmannianum CCMP683) [46] at $20-22{ }^{\circ} \mathrm{C}$ under constant illumination either from Cool White or Grow-Lux wide spectrum lamps. RE medium is based on previously described media such as ASP-M [47] and L1 [48] but differs from most media by the inclusion of high concentrations of biotin and vitamin B12. The RE medium consists of nine separately sterilized solutions (autoclaved unless otherwise noted): (1) $1 \mathrm{~L}$ artificial seawater containing per liter: $23.38 \mathrm{~g} \mathrm{NaCl}, 4.93 \mathrm{~g} \mathrm{MgSO}_{4} \bullet 7 \mathrm{H}_{2} \mathrm{O}, 4.06 \mathrm{~g} \mathrm{MgCl}_{2} \bullet 6 \mathrm{H}_{2} \mathrm{O}$, $0.75 \mathrm{~g} \mathrm{KCl}, 0.2 \mathrm{~g} \mathrm{KBr}$, and $12.4 \mathrm{mg} \mathrm{H}_{3} \mathrm{BO}_{3}$; (2) $1 \mathrm{ml} \mathrm{RE}$ trace metals containing per liter: $200 \mathrm{mg}$ $\mathrm{MnSO}_{4} \cdot \mathrm{H}_{2} \mathrm{O}, 200 \mathrm{mg} \mathrm{Na} \mathrm{MoO}_{4} \cdot 2 \mathrm{H}_{2} \mathrm{O}, 100 \mathrm{mg} \mathrm{ZnSO} 4 \cdot 7 \mathrm{H} 2 \mathrm{O}, 20 \mathrm{mg} \mathrm{CuSO} 4 \cdot 5 \mathrm{H} 2 \mathrm{O}, 20 \mathrm{mg}$ $\mathrm{CoCl}_{2} \cdot 6 \mathrm{H}_{2} \mathrm{O}, 20 \mathrm{mg} \mathrm{NiSO} 4 \cdot 6 \mathrm{H} 2 \mathrm{O}, 1.84 \mathrm{mg} \mathrm{Na} \mathrm{VO}_{4}$, and $1.73 \mathrm{mg} \mathrm{Na}_{2} \mathrm{SeO}_{3}$; (3) $1 \mathrm{ml} \mathrm{RE}$ vitamins, filter sterilized, contained per liter: $200 \mathrm{mg}$ vitamin B12 (cyanocobalamine), $200 \mathrm{mg}$ thiamine-HCl, and $100 \mathrm{mg}$ biotin; (4) $1 \mathrm{ml} \mathrm{NaNO} 3(75 \mathrm{~g} / \mathrm{L})$; (5) $1 \mathrm{ml} \mathrm{NaH} 2 \mathrm{PO} 4 \cdot \mathrm{H} 2 \mathrm{O}(5 \mathrm{~g} / \mathrm{L})$; (6) $10 \mathrm{ml} \mathrm{CaCl} \cdot 2 \mathrm{H} 2 \mathrm{O}$ (147 g/L); (7) $5 \mathrm{ml}$ Trizma $\mathrm{pH} 8.1$ to 8.2 (279.6 g preset crystals/L); (8) $2 \mathrm{ml} \mathrm{NaHCO}_{3}(84 \mathrm{~g} / \mathrm{L})$; (9) $1 \mathrm{ml} \mathrm{FeSO} \cdot 7 \mathrm{H} 2 \mathrm{O}(3.06 \mathrm{~g} / \mathrm{L}$ freshly prepared and filter sterilized). 


\subsection{Amplification, cloning and sequencing of PKS and $16 S$ genes}

\subsubsection{DNA Extraction from dinoflagellates}

Approximately $1 \mathrm{ml}$ of dinoflagellate culture was pelleted by centrifugation at $10,000 \mathrm{x} \mathrm{g}$ for 2 minutes. Genomic DNA (50-100 $\mu$ volume) was extracted according to manufacturer's instructions (Qiagen Bio101 fast DNA kit) using matrix \#2 and buffer CLS-Y. The cells were lysed using three cycles of 20 seconds each on the FastPrep FP120 cell disrupter set to speed 4.5. The DNA was quantitated using a $\mu$ Quant plate reader and diluted to $100 \mathrm{ng} / \mu \mathrm{l}$ for PCR.

\subsubsection{Isolation of bacteria from P. lima}

A non-axenic unialgal culture of $P$. lima was used to isolate bacteria associated with the dinoflagellate. The culture was filtered using glass fiber disks and the filtrate re-filtered using a nylon membrane with a $10 \mu \mathrm{m}$ pore size in order to remove dinoflagellate cells. The filters were washed with fresh liquid medium (Prov 50) in order to dislodge surface bacteria. The filtrate from the nylon membrane was again passed through a $5 \mu \mathrm{m}$ pore size membrane. Finally, the bacteria were collected and concentrated (to $50 \mathrm{ml}$ from $4 \mathrm{~L}$ ) using a Millipore lab scale tangential flow filtration (TFF) system equipped with a $0.22 \mu \mathrm{m}$ filter. The bacterial fraction (named TFF-Bac) was centrifuged at 30,000 x $\mathrm{g}$ on a Sorvall super T 21 centrifuge for 1 hour at room temperature. Genomic DNA was extracted from the bacterial pellet after proteinase K digestion [49]. The DNA was screened, and found to be negative, for eukaryotic contamination by small subunit ribosomal RNA (18S) PCR. Additionally, a PKS library of the TFF Bac was prepared to help assess the origin of PKS genes found in the dinoflagellate cultures.

\subsubsection{Polymerase Chain Reaction (PCR)}

The $50 \mu \mathrm{l}$ reactions contained $200 \mathrm{ng}$ of DNA, 1X NEB Thermopol buffer, $7 \%$ DMSO, $2.5 \mathrm{mM}$ $\mathrm{MgCl}_{2}, 0.25 \mathrm{nmol}$ each $\mathrm{dNTP}, 1 \mu \mathrm{mol}$ each primer, and 1.0U Taq polymerase. PCR reactions were initiated with a denaturing temperature of $95{ }^{\circ} \mathrm{C}$ for 2 minutes. followed by the appropriate cycling conditions $\left(28\right.$ cycles of $95{ }^{\circ} \mathrm{C}, 30$ seconds; $55{ }^{\circ} \mathrm{C}, 30$ seconds, then 1 cycle of $72{ }^{\circ} \mathrm{C}, 1$ minute 30 seconds for $16 \mathrm{~S}$ PCR or 40 cycles of $95{ }^{\circ} \mathrm{C}, 45$ seconds; $52{ }^{\circ} \mathrm{C}, 1$ minute 30 seconds, then 1 cycle of $72{ }^{\circ} \mathrm{C}, 2$ minutes for PKS PCR).

\subsubsection{Amplicon Purification and Cloning}

PCR amplicons were visualized on $1.25 \%$ agarose gels using $1 \mathrm{X}$ modified-TAE buffer for gel preparation and electrophoresis. The modified buffer is included in the Montage DNA gel extraction kit (Millipore) and contains a lower concentration of EDTA to prevent interference with enzyme used in further applications. The gels were stained using 2X SYBR gold DNA stain and visualized using a Dark Reader (Claire Chemical Research Inc.). Bands of the anticipated size were excised from the gel and purified using the Montage kit. The DNA was precipitated overnight at $-20{ }^{\circ} \mathrm{C}$ in 0.1 volumes $3 \mathrm{M}$ $\mathrm{NaOAc}(\mathrm{pH} \mathrm{5.2)}$ and 2 volumes EtOH. Following centrifugation at 20,000 x g for 90 minutes, the DNA was reconstituted in $20 \mu \mathrm{l}$ of $\mathrm{sdH}_{2} \mathrm{O}$. 
Using the TOPO cloning kit (Invitrogen), $2 \mu$ of the purified DNA was ligated into a pCR 2.1 cloning vector according to the manufacturer's instructions. One Shot Top 10 chemically competent $E$. coli cells were transformed and incubated for 1 hour in SOC media at $37^{\circ} \mathrm{C}$. LB-agar plates containing $100 \mu \mathrm{g} / \mathrm{ml}$ of ampicillin were covered with $20 \mu \mathrm{l}$ of $40 \mathrm{mg} / \mathrm{ml} \mathrm{X-gal} \mathrm{(5-bromo-4-chloro-3-indolyl-} \beta$-Dgalactopyranoside) for blue/white screening of clonal colonies. Each plate was inoculated with $10 \mu$, $50 \mu \mathrm{l}$, or $100 \mu \mathrm{l}$ of SOC culture and incubated at $37{ }^{\circ} \mathrm{C}$ overnight. Colonies (48 per sample), were picked and streaked on an LB-amp plate for purity. From these plates, a single colony was selected and used to inoculate $3 \mathrm{ml} \mathrm{LB}$-amp liquid cultures for overnight incubation. Plasmids were purified using the Qiagen QiaPrep miniprep kit and diluted to a final concentration of $250 \mathrm{ng} / \mu \mathrm{l}$.

\subsubsection{Sequencing Reactions}

Sequencing reactions were conducted on the Eppendorf mastercycler using a 96-well plate format. Each $10 \mu \mathrm{l}$ reaction contained $250 \mathrm{ng}$ of plasmid DNA, 1X reaction buffer, 1/16X Big Dye 3.1, and 4.8 pmol of the M13 reverse sequencing primer. The labeled products were amplified using 40 cycles of $95{ }^{\circ} \mathrm{C}$ for 15 seconds, $50{ }^{\circ} \mathrm{C}$ for 20 seconds, and $60{ }^{\circ} \mathrm{C}$ for 4 minutes. Sequencing was performed on an ABI 3730 sequencer (Applied Biosystems, CA). The resulting sequences, on average $500 \mathrm{bp}$ each, were assembled and aligned using the programs SeqMan and MegAlign (Lasergene). Additionally, sequences were submitted to nucleotide BLASTN and translated-BLASTX analysis for identification [50]. One clone from each unique PKS group was sequenced in both directions by MWG biotech, using T3 or T7 primers to provide a full length sequence for the amplicon. 16S sequences were submitted to BLASTN for best match identification. Sequences have been submitted to Genbank. Accession numbers will be provided at the time of publication.

\subsection{Phylogenetic analysis}

Most phylogenetic analyses of PKS sequences followed methods previously described [45, 29]. Several reference PKS amino acid sequences were also previously documented, while the following PKS sequences were retrieved for this study: Halomonas AAX51692, Halomonas PKS AY851763, Roseobacter ZP_01755301, Phaeobacter inhibens AY841765, Nodularia spumigena AAO64407.1, unknown marine bacterium AAX51693.1, Nodularia spumigena AAO64407.1, Magnetospirillum gryphiswaldense CAM74077.1, Methanosarcina mazei AAM30566.1, Picrophilus torridus AAT43773.1.

Phylogenetic analysis began by aligning sequences using CLUSTALX [51]. For 16S sequences, after manually checking alignments by comparing with known secondary structure models [52], poorly aligned SSU rRNA regions (e.g. high number of gaps or indels) were omitted from further analysis. Alignments were then imported into PAUP (phylogenetic analysis using parsimony) v 4.0b3a [53], which allowed a comparison of various phylogenetic algorithms and substitution models. Due to the large amount of sequence divergence in most PKS datasets, minimum evolutionary tree topologies based on distance models (neighbor-joining), maximum parsimony and maximum likelihood were obtained using heuristic methods. Each reconstructed group was statistically evaluated by bootstrapping with a minimum number of 500 replicates $[54,55]$. Most appropriate DNA substitution models for distance algorithms were determined using MODELTEST [56]. 


\subsection{Protein Phophatase (PP2A) inhibition assay}

Two-hundred $\mathrm{mL}$ of each culture were centrifuged at $1020 \mathrm{Xg}$ for 15 minutes and filtered through a G6 glass fiber filter. The supernatant was passed through a $2 \mathrm{~g} \mathrm{C}-18$ SPE column, washed with water $(30 \mathrm{~mL})$ and eluted with $\mathrm{MeOH}(50 \mathrm{~mL})$. The $\mathrm{MeOH}$ was dried in vacuuo and the residue was resuspended in $1 \mathrm{~mL}$ of $\mathrm{MeOH}$. Dilutions of this extract were used for both the PP2A inhibition assay and the okadaic acid ELISA.

The PP2A inhibition assay, modified from Simon [57] and Tubaro [58], was conducted as follows: each sample was prepared in $20 \mu \mathrm{l}$ of $50 \% \mathrm{MeOH}$ in $\mathrm{H}_{2} \mathrm{O}$ and combined with $0.15 \mathrm{U}$ of PP-2A in $20 \mu \mathrm{l}$ of buffer containing Tris (50 mM, pH: 7.4), $\mathrm{Na}_{2}$ EDTA $(10 \mathrm{mM}), \mathrm{MnCl}_{2}(10 \mathrm{mM}), 1.3 \mu \mathrm{BSA}$ $(0.1 \mu \mathrm{g} / \mu \mathrm{l}), 0.15 \mu \mathrm{g}$ Dithiothreitol (DTT) in $\mathrm{H}_{2} \mathrm{O}$. The sample was then combined with $180 \mu \mathrm{l}$ of buffer containing $0.5 \mathrm{mg}$ of pNPP, Tris (50 mM, pH: 8.1), $\mathrm{MgCl}_{2}(4 \mathrm{mM})$ and $\mathrm{MnCl}_{2}(0.4 \mathrm{mM})$ allowed to incubate for 2 hours at room temperature and read using a Bio-Tek Instruments $\mu$ Quant plate reader scanning at $405 \mathrm{~nm}$. A standard curve was prepared with pure OA, prepared exactly as the samples, using serial dilutions from $20 \mathrm{nM}$ to $0.625 \mathrm{nM} \mathrm{OA}$ in $50 \% \mathrm{MeOH}$.

\subsection{OA/ DTX ELISA}

The okadaic acid ELISA was performed according to the manufacturer's (Abraxis) instruction, using the methanol solution prepared for the PP2A inhibition assay (section 3.4). Serial dilutions were performed in the assay buffer, such that the concentration of OA equivalents was in the quantifiable range.

\section{Acknowledgements}

This work was supported by the National Institute of Environmental Health Sciences (NIEHS) Grant S11 ES11181, the NSF-NIEHS Oceans and Human Health Center Program (National Science Foundation grant 0432368 and NIEHS grant P50 ES12736-01) and the USDA grant NRICGP 200235201-11671. The authors would like to thank Jamie Winshell and Gordana Simovic for expert technical assistance with algal cultures.

\section{References and Notes}

1. Hernandez-Becerril, D.U.; Cortes Altamirano, R.; Alonso R. The dinoflagellate genus Prorocentrum of the Mexican Pacific. Hydrobiol. 2000, 418,111-121.

2. Gestal-Otero, J. J., Seafood and freshwater toxins. Food Science and Technology 2000, 103, 4564.

3. Balmer-Hanchey, E. L.; Jaykus, L.; Green, D. P.; McClellan-Green, P. J. Marine biotoxins of algal origin and seafood safety. Aquat. Food Prod. Technol. 2003, 12, 29-53.

4. Tachibana, K.; Scheuer, P. J.; Tsukitani, Y.; Kikuchi, H.; Van Engen, D.; Clardy, J.; Gopichand, Y.; Schmitz, F. J. Okadaic acid, a cytotoxic polyether from two marine sponges of the genus Halichondria. J. Am. Chem. Soc. 1981, 103, 2469-2471.

5. Yasumoto, T.; Seino, N.; Murakami, Y.; Murata, M. Toxins produced by benthic dinoflagellates. Biological Bulletin (Woods Hole, MA, United States) 1987, 172, 128-131. 
6. Murakami, Y.; Oshima, Y.; Yasumoto, T. Identification of okadaic acid as a toxic component of a marine dinoflagellate Prorocentrum lima. Nippon Suisan Gakkaishi 1982, 48, 69-72.

7. Dickey, R. W.; Bobzin, S. C.; Faulkner, D. J.; Bencsath, F. A.; Andrzejewski, D. Identification of okadaic acid from a Caribbean dinoflagellate, Prorocentrum concavum Toxicon 1990, 28, 371377.

8. Zhou, J.; Fritz, L. Ultrastructure of two toxic marine dinoflagellates, Prorocentrum lima and Prorocentrum maculosum. Phycologia 1993, 32, 444-450.

9. Morton, S. L.; Moeller, P. D.; Young, K. A.; Lanoue, B. Okadaic acid production from the marine dinoflagellate Prorocentrum belizeanum Faust isolated from the Belizean coral reef ecosystem. Toxicon: official journal of the International Society on Toxinology 1998, 36, 201-206.

10. Morton, S. L. Morphology and toxicology of Prorocentrum fausitae sp. nov., a toxic species of non-planktonic dinoflagellate from Heron Island Australia. Bot. Mar. 1998, 41, 565-569.

11. Ten-Hage, L.; Delaunay, N.; Pichon, V.; Coute, A.; Puiseux-Dao, S.; Turquet, J. Okadaic acid production from the marine benthic dinoflagellate Prorocentrum arenarium Faust (Dinophyceae) isolated from Europa Island coral reef ecosystem. Toxicon 2000, 38, 1043-1054.

12. Draisci, R.; Giannetti, L.; Lucentini, L.; Marchiafava, C.; James, K. J.; Bishop, A. G.; Healy, B. M.; Kelly, S. S. Isolation of a new okadaic acid analog from phytoplankton implicated in diarrhetic shellfish poisoning. J. Chromatogr. A 1998, 798, 137-145.

13. Murata, M.; Shimatani, M.; Sugitani, H.; Oshima, Y.; Yasumoto, T. Isolation and structure elucidation of the causative toxin of the diarrhetic shellfish poisoning. Nippon Suisan Gakkaishi 1982, 48, 549-552.

14. Murata, M.; Murakami, Y.; Kumagai, M.; Yanagi, T.; Yasumoto, T.; Iwashita, T.; Naoki, H. okadaic acid and its derivatives as diarrhetic shellfish toxins. Tennen Yuki Kagobutsu Toronkai Koen Yoshishu 1986, 28th, 192-199.

15. Schmitz, F. J.; Prasad, R. S.; Gopichand, Y.; Hossain, M. B.; Van der Helm, D.; Schmidt, P. Acanthafolicin, a new episulfide-containing polyether carboxylic acid from extracts of the marine sponge Pandaros acanthifolium. J. Am. Chem. Soc. 1981, 103, 2467-2469.

16. Suarez-Gomez, B.; Souto, M. L.; Norte, M.; Fernandez, J. J. Isolation and structural determination of DTX-6, a new okadaic acid derivative. J. Nat. Prod. 2001, 64, 1363-1364.

17. Suarez-Gomez, B.; Souto, M. L.; Cruz, P. G.; Fernandez, J. J.; Norte, M. New targets in diarrhetic shellfish poisoning control. J. Nat. Prod. 2005, 68, 596-599.

18. Suzuki, T.; Beuzenberg, V.; Mackenzie, L.; Quilliam, M. A. Discovery of okadaic acid esters in the toxic dinoflagellate Dinophysis acuta from New Zealand using liquid chromatography/tandem mass spectrometry. Rapid Commun. Mass Spectrom. 2004, 18, 1131-1138.

19. Hu, T.; Marr, J.; DeFreitas, A. S. W.; Quilliam, M. A.; Walter, J. A.; Wright, J. L. C.; Pleasance, S. New diol esters isolated from cultures of the dinoflagellates Prorocentrum lima and Prorocentrum concavum. J. Nat. Prod. 1992, 55, 1631-1637.

20. Hu, T.; deFreitas, A. S. W.; Doyle, J.; Jackson, D.; Marr, J.; Nixon, E.; Pleasance, S.; Quilliam, M. A.; Walter, J. A.; Wright, J. L. C. New DSP toxin derivatives isolated from toxic mussels and the dinoflagellates, Prorocentrum lima and Prorocentrum concavum. Developments in Marine Biology 1993, 3, 507-512. 
21. Hu, T.; deFreitas, A. S. W.; Doyle, J.; Jackson, D.; Marr, J.; Nixon, E.; Pleasance, S.; Quilliam, M. A.; Walter, J. A.; Wright, J. L. C. Developments in Marine Biology 1993, 3, 507-512.

22. Fernandez, J. J.; Suarez-Gomez, B.; Souto, M. L.; Norte, M. Identification of new okadaic acid derivatives from laboratory cultures of Prorocentrum lima. J. Nat. Prod. 2003, 66, 1294-1296.

23. Dounay, A. B.; Forsyth, C. J. Okadaic acid: the archetypal serine/threonine protein phosphatase inhibitor. Curr. Med. Chem. 2002, 9, 1939-1980.

24. Needham, J.; McLachlan, J.L.; Walter, J.A.; Wright, J.L.C. Biosynthetic origin of C-37 and C-38 in the polyether toxins okadaic acid and dinophysistoxin-1. J. Chem. Soc., Chem. Comm., 1994, 2599-2600.

25. Wright, J.L.C.; Hu, T.; McLachlan, J.L.; Needham, J.; and Walter, J.A. Biosynthesis of DTX-4: Confirmation of a polyketide pathway, proof of a Baeyer-Villiger oxidation step, and evidence for an unusual carbon deletion process. J. Am. Chem. Soc, 1996, 118, 8757-8758.

26. Macpherson, G.R.; Burton, I.W.; LeBlanc, P.; Walter, J.A.; and Wright, J.L.C. Studies of the biosynthesis of DTX-5a and DTX-5b by the dinoflagellate Prorocentrum maculosum: regiospecificity of the putative Baeyer-Villigerase and insertion of a single amino acid in a polyketide chain. J. Org. Chem., 2003, 68, 1659-1664.

27. Van Lanen, S. G.; Shen, B. Advances in polyketide synthase structure and function. Curr. Op. Drug. Dis. \& Dev. 2008, 11, 186-195.

28. Seshime, Y.; Juvvadi, P. R.; Fujii, I.; Kitamoto, K. Discovery of a novel superfamily of type III polyketide synthases in Aspergillus oryzae. Biochem. Biophys. Res. Commun. 2005, 331, 253-260.

29. Snyder, R. V.; Gibbs, P. D. L.; Palacios, A.; Abiy, L.; Dickey, R.; Lopez, J. V.; Rein, K. S. Polyketide synthase genes from marine dinoflagellates. Marine Biotechnology 2003, 5, 1-12.

30. Zhu, G.; LaGier, M. J.; Stejskal, F.; Millership, J. J.; Cai, X.; Keithly, J. S. Cryptosporidium parvum: the first protist known to encode a putative polyketide synthase. Gene 2002, 298, 79-89.

31. De Traubenberg, C. R.; Geraud, M. L.; Soyer-Gobillard, M. O.; Emdadi, D. The toxic dinoflagellate Prorocentrum lima and its associated bacteria. I. An ultrastructural study. Eur. J. Protistol. 1995, 31, 318-326.

32. De Traubenberg, C. R.; Soyer-Gobillard, M. O. Bacteria associated with a photosynthetic dinoflagellate in culture. Symbiosis 1990, 8, 117-133.

33. Biegala, I. C.; Kennaway, G.; Alverca, E.; Lennon, J.; Vaulot, D.; Simon, N. Identification of bacteria associated with dinoflagellates (Dinophyceae) Alexandrium spp. using tyramide signal amplification-fluorescent in situ hybridization and confocal microscopy. J. Phycol. 2002, 38, 404411.

34. Maki, T.; Imai, I. Relationship between intracellular bacteria and the bivalve killer dinoflagellate Heterocapsa circularisquama (dinophyceae). Fisheries Science 2001, 67, 794-803.

35. Lucas, A. N.; Vesk, M. The fine structure of two photosynthetic species of Dinophysis (Dinophyceae). J. Phycol. 1990, 26, 345-357.

36. LaFay, B.; Ruimy, R.; De Traubenberg, C. R.; Breittmayer, V.; Gauthier, M. J.; Christen, R. Roseobacter algicola sp. nov., a new marine bacterium isolated from the phycosphere of the toxin-producing dinoflagellate Prorocentrum lima. Int. J. Sys. Bacterio. 1995, 45, 290-296. 
37. Prokic, I.; Brummer, F.; Brigge, T.; Gortz, H. D.; Gerdts, G.; Schutt, C.; Elbrachter, M.; Muller, W. E. G. Bacteria of the genus Roseobacter associated with the toxic dinoflagellate Prorocentrum lima. Protist. 1998, 149, 347-357.

38. Scorzetti, G.; Brand, L. E.; Hitchcock, G. L.; Rein, K. S.; Sinigalliano, C.; Fell, J. W. Multiple simultaneous detection of Harmful Algal Bloom (HABs) through a high throughput bead array technology, with potential use in phytoplankton community analysis. Harmful Algae 2008, (in press).

39. Loeblich, A. R. In Dinoflagellate evolution; Spector, D. L., Ed.; Dinoflagellates. Academic Press Inc.,: Orlando, FL., 1984; pp 482-516.

40. Faust, M. A. Morphologic details of six benthic species of Prorocentrum (Pyrrophyta) from a mangrove island, Twin Cays, Belize, including two new species. J. Phycol. 1990, 26, 548-558.

41. Steidinger, K. A. A re-evaluation of the toxic dinoflagellate biology and ecology. Progr. Phycol. Res. 1983, 2, 147-188.

42. Cortes-Altamirano, R.; Sierra-Beltran, A. P. Morphology and taxonomy of Prorocentrum mexicanum and reinstatement of Prorocentrum rhathymum (Dinophyceae). J. Phycol. 2003, 38, 221-225.

43. De Traubenberg, C. R. Interaction entre un dinoflagelle et sa microflore bacterienne associee: role des bacteries dans la toxicite de Prorocentrum lima Ehrenberg (Dodge). Universite de Nantes, Nantes, France, 1993.

44. Martens, T.; Gram, L.; Grossart, H.; Kessler, D.; Mueller, R.; Simon, M.; Wenzel, S. C.; Brinkhoff, T. Bacteria of the Roseobacter clade show potential for secondary metabolite production. Microb. Ecol. 2007, 54, 31-42.

45. Snyder, R. V; Guerrero M. A; Sinigalliano C. D; Winshell J.; Perez R.; Lopez J. V; Rein K. S Localization of polyketide synthase encoding genes to the toxic dinoflagellate Karenia brevis. Phytochemistry 2005, 66(15), 1767-80.

46. Guillard, R. R. L. In Culture of phytoplankton for feeding marine invertebrates. In Cult. Mar. Invertebr. Anim., 1975; pp 29-60.

47. McLachlan, J. Some consideration of the growth of marine algae in artificial media. Can. J. Microbiol. 1964, 10, 769-782.

48. Guillard, R. R. L. In 1995. Culture methods; Hallegraeff, G. M., Anderson, D. M. and Cembella, A. D., Eds.; Manual on Harmful Marine Microalgae. UNESCO Publishing: New York, 1995; pp 45-62.

49. Sambrook, J. D.; Russell, W.; Maniatis, T. In Molecular cloning : a laboratory manual; Cold Spring Harbor Laboratory Press: Cold Spring Harbor, N.Y., 2001; .

50. Altschul, S. F.; Madden, T. L.; Schaffer, A. A.; Zhang, J.; Zhang, Z.; Miller, W.; Lipman, D. J. Gapped BLAST and PSI-BLAST: a new generation of protein database search programs. Nucleic Acids Res. 1997, 25, 3389-3402.

51. Thompson, J. D.; Gibson, T. J.; Plewniak, F.; Jeanmougin, F.; Higgins, D. G. The CLUSTAL_X windows interface: flexible strategies for multiple sequence alignment aided by quality analysis tool. Nucleic Acids Res. 1997, 25, 4876-4882. 
52. Sfanos, K. A. S.; Harmody, D. K.; McCarthy, P. J.; Dang, P.; Pomponi, S. A.; Lopez, J. V. Systematic survey of cultured microbial associates of deep water marine invertebrates. Syst. Appl. Microbiol. 2005, 28, 242-264.

53. Swofford, D.L. 2002. PAUP* Phylogenetic analysis using parsimony (*and other methods). Version 4. Sinauer, Sunderland Mass.

54. Felsenstein, J. Confidence limits on phylogenetics: An approach using the bootstrap. Evolution 1985, 39, 783-791.

55. Nei, M.; Kumar, S. In Molecular Evolution and Phylogenetics; Oxford University: Oxford, 2000.

56. Posada, D.; Crandall, K. A. MODELTEST: testing the model of DNA substitution. Bioinformatics 1998, 14, 817-818.

57. Simon, J. F.; Vernoux, J. P. Highly sensitive assay of okadaic acid using protein phosphatase and paranitrophenyl phosphate. Nat. Tox. 1994, 2, 293-301.

58. Tubaro, A.; Florio, C.; Luxich, E.; Sosa, S.; Loggia, R. D.; Yasumoto, T. A protein phosphatase 2A inhibition assay for a fast and sensitive assessment of okadaic acid and contamination in mussels. Toxicin 1996, 34, 743-652.

Samples Availability: Dinoflagellate strains used in this study are available from the ProvasoliGuillard Center for the Culture of Marine Phytoplankton (CCMP). Sixteen nucleotide sequences for PKS amplicons have been deposited to GenBank; Accession numbers EU698032 - EU698047

(C) 2008 by the author(s); licensee Molecular Diversity Preservation International, Basel, Switzerland. This article is an open-access article distributed under the terms and conditions of the Creative Commons Attribution license (http://creativecommons.org/licenses/by/3.0/). 